\title{
Soil Moisture Patterns on Two Chained Pinyon-Juniper Sites in Utah
}

\author{
GERALD F. GIFFORD AND CONNOR B. SHAW
}

Highlight: Soil moisture patterns were studied under chaining-with-windrowing, chaining-with-debris-in-place, and natural woodland at one site each in both southwestern and southeastern Utah. Results of the study indicate the greatest moisture accumulation occurred under the debris-in-place treatment (as compared to woodland controls), during the first 6 months of each year at Milford and regardless of season at Blanding. The woodland had the least soil moisture throughout most of each year. Most moisture flux took place in the upper 60- to 90-cm of soil profile, with only minor changes occurring at greater depths. Differences in soil moisture patterns have been attributed to changes in microclimates due to chaining, different rooting depths and length of growing season, mulching effect of litter on the debris-in-place treatment, and possible differences in snow accumulation. Variation in vegetation density on the chained treatments did not influence soil moisture patterns. There was no evidence of deep seepage on any chaining treatment at either site.

Soil moisture patterns as influenced by vegetation manipulation practices have not received a great deal of attention in the pinyon-juniper (Pinus edulis-Juniperus osterosperma) type. Only Skau (1964) has published on this aspect, and he found in Arizona that clearing alligator juniper (J. deppeana) and Utah juniper had little effect on water yields as influenced by soil water storage in the upper $60 \mathrm{~cm}$ of the soil profile. He made nine measurements of soil moisture under cleared versus natural woodland from late June of 1959 through early December, 1960. Calibrated watershed studies described by Brown (1971) and Collings and Myrick (1966) relate to soil moisture patterns, but only indirectly.

The objective of this study was to determine if there were significant differences in soil moisture accumulation among three pinyon-juniper treatments in both southwestern and southeastern Utah. The treatments included natural woodland, chaining-with-debris-in-place, and chaining-with-windrowing.

\section{Site Descriptions and Methods}

The soil moisture study was undertaken at two locations in southern Utah (Fig. 1). One site is located about $72 \mathrm{~km}$ southwest of Milford and the other site about $70 \mathrm{~km}$ west of Blanding.

The chaining treaments ( 12 to 16 ha each) were performed during the fall of 1967 at both sites, and the areas fenced to

Authors are associate professor and graduate research assistant, Range Watershed Science, Watershed Science Unit, Utah State University, Logan.

This study was conducted in cooperation with the Bureau of Land Management under contract 14-11-0008-2837. (Journal paper 1310,

Utah Agricultural Experiment Station, Utah State University, Logan.) Manuscript received November 11, 1972.

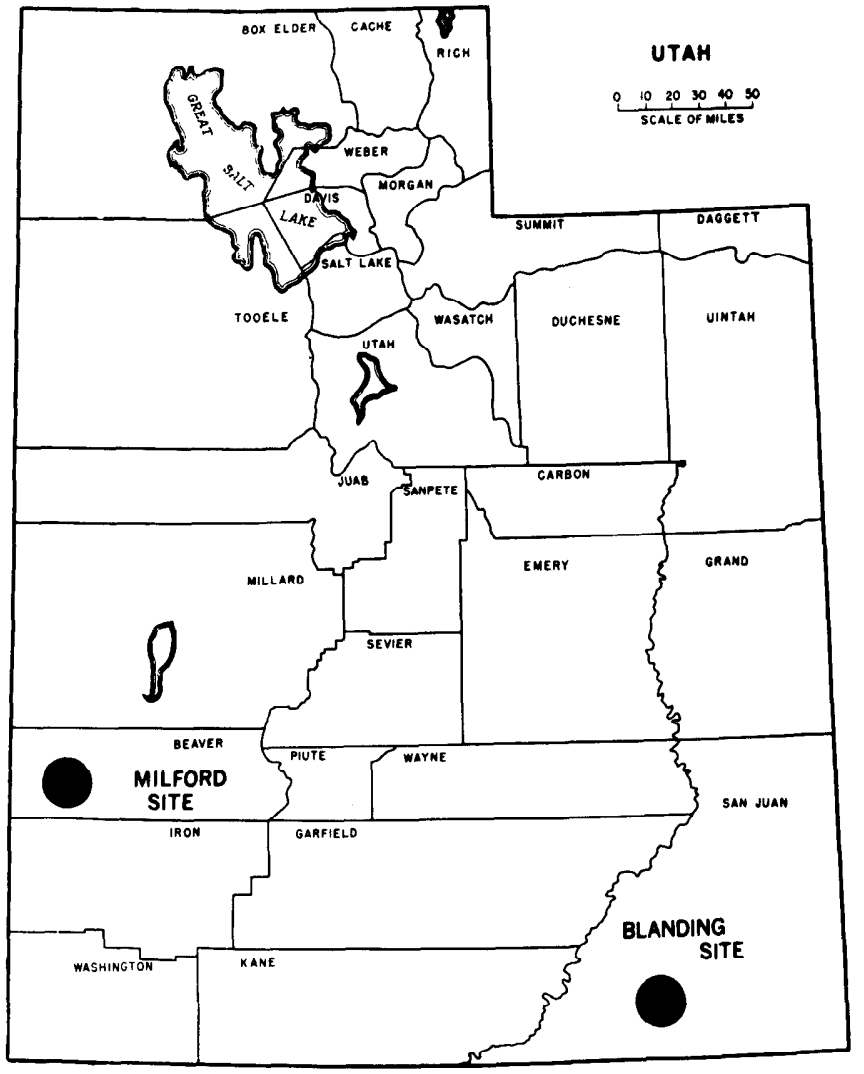

Fig. 1. Map showing general location of the two study sites in southeastern and southwestern Utah.

exclude livestock. Chaining involves pulling a large anchor chain between two tractors to fell the pinyon and juniper trees. The windrowed areas (all debris pushed into windrowsFigure 2) were drill seeded with crested wheatgrass at 9.1 $\mathrm{kg} / \mathrm{ha}$; the debris-in-place areas (debris left where it fell-Figure 3) were broadcast seeded at the same rate.

The Milford site is within the Basin and Range Province at an clcvation of approximately $2,000 \mathrm{~m}$. Parent material of the soil is basaltic rock. Soil profile depth is $1.3 \mathrm{~m}$. Soil texture varies from sandy loam to loam, and the average rock content (by weight) of the soil is $35 \%$. The mature woodland has a canopy cover which averages $15 \%$ juniper ( 350 trees/ha) and $10 \%$ pinyon (125 trees/ha). Brush cover averages $7 \%$ and is composed of big sagebrush (Artemisia tridentata), black sagebrush (Artemisia nova), and broom snakeweed (Gutierrezia sarothrae). Small amounts of phlox (Phlox spp.), Lupine spp., Eriogonium spp., Penstemon spp., and Indian ricegrass (Oryzopsis hymenoides) also occur as part of the understory. 


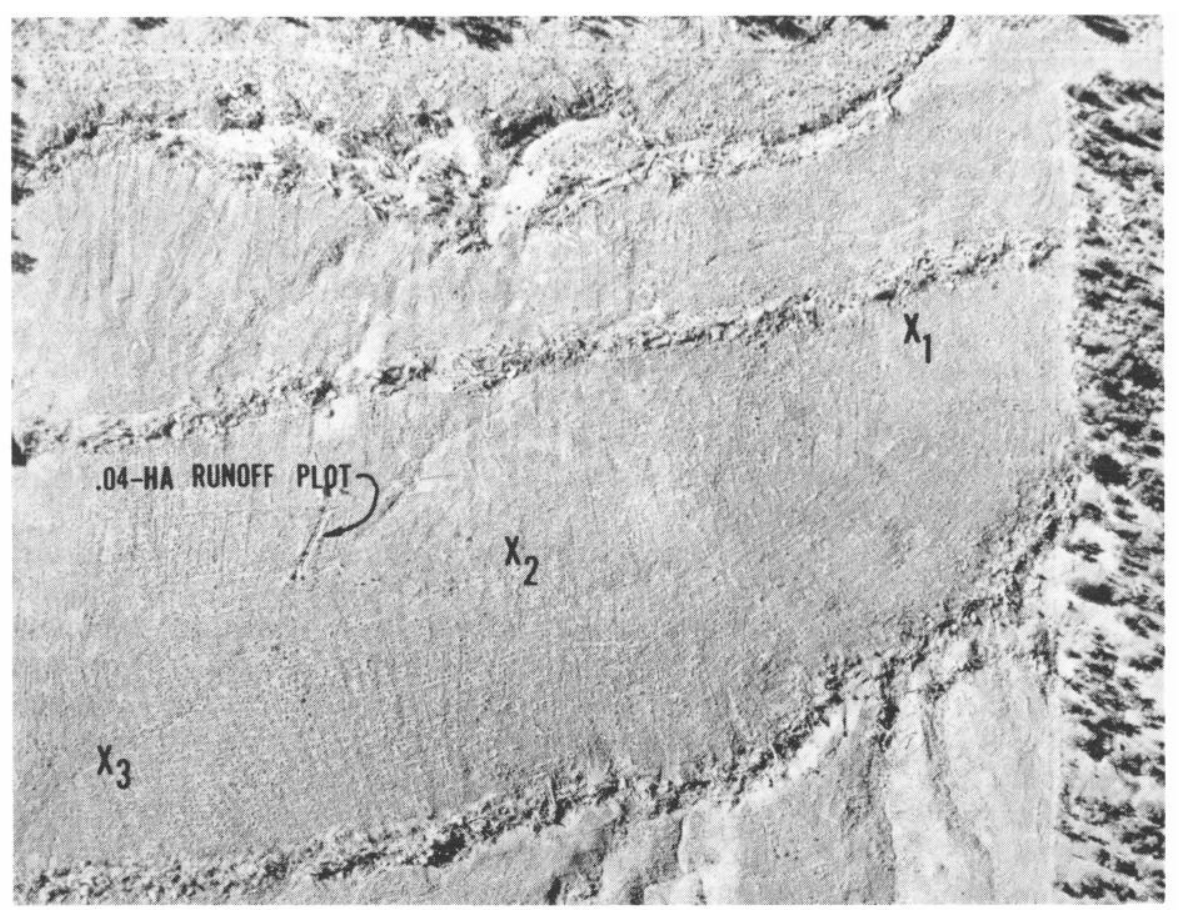

Fig. 2. Aerial view of chain-with-windrowing treatment at Blanding study site showing location of soil moisture access tubes (see text) between windrows. Barely visible is one of several .04-hectare runoff plots being used for other studies. Photo scale is $1 \mathrm{~cm}=21$ meters.

Fig. 3. Aerial view of chain-with-debris-in-place treatment at Blanding study site. Photo scale is $1 \mathrm{~cm}=21$ meters.

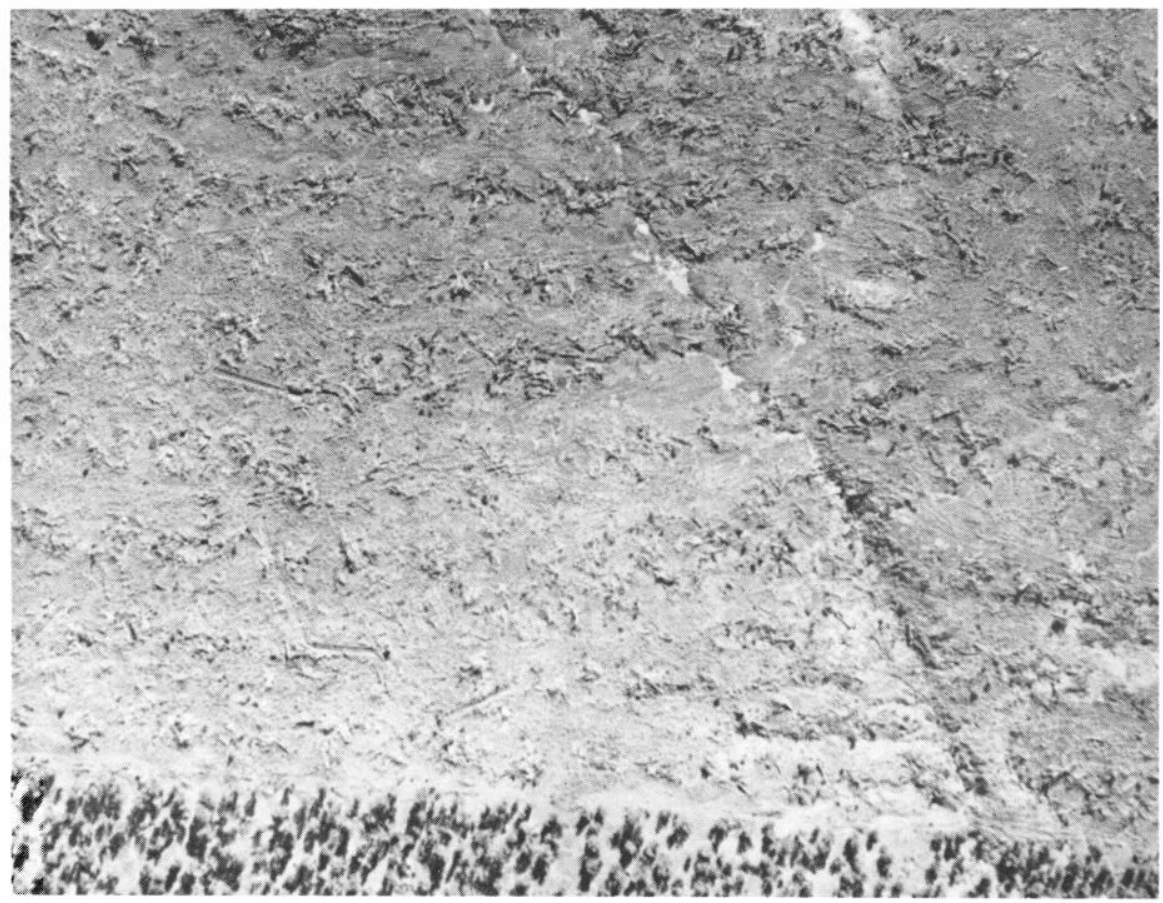

The chaining-with-debris-in-place treatment at Milford has a 5 to $10 \%$ cover of big sagebrush and about the same amount of broom snakeweed. Ground cover consisted primarily of weakly developed erosion pavement (30-60\%), litter (20-45\%), crested wheatgrass (Agropyron cristatum, 10-15\%), and the balance bare ground. The chain-with-windrowing treatment had from 15 to $40 \%$ erosion pavement, 30 to $60 \%$ bare soil, 15 to $35 \%$ crested wheatgrass, and the balance litter. Cover percentages are taken from line transect data collected on each treatment. Annual precipitation during the 3-year study (as measured on site) averaged $240 \mathrm{~mm}$.

The Blanding site is within the Colorado Plateau at an elevation of about $2,150 \mathrm{~m}$. The parent material of the soil is primarily sandstone; the soil profile depth is $1.5 \mathrm{~m}$. Soil texture is primarily sandy loam with few, if any, rocks present. The canopy cover of mature juniper (500 trees/ha) and pinyon (200 trees/ha) averages 24 and $8 \%$, respectively. Shrub cover is less than $1 \%$ and consists of big sagebrush. Bare ground and litter make up the balance. The bare ground category actually includes some cryptogam species present in the surface $3 \mathrm{~cm}$ of soil.

The chaining-with-debris-in-place treatment at Blanding has a ground cover which consists primarily of 25 to $45 \%$ bare ground, 30 to $60 \%$ litter, and 12 to $20 \%$ crested wheatgrass. The chain-with-windrowing treatment has from 40 to $65 \%$ bare ground, 15 to $30 \%$ litter, and 17 to $25 \%$ crested wheatgrass cover. Average annual precipitation during the 2-year study was nearly identical to the $240 \mathrm{~mm}$ measured at 


\section{Milford.}

Soil moisture measurements at both the Milford and Blanding sites were taken with a Troxler depth moisture probe (Model 56A. Model 105A) and scaler (Model 399C). Neutron measurements were taken at $30 \mathrm{~cm}$ increments, starting $15 \mathrm{~cm}$ below the soil surface. Compaction of soil around access tubes was minimized by using a small platform for support while taking neutron readings at each tube. From June through September soil moisture was measured approximately once every 2 to 3 weeks. Measurements were less frequent other parts of the year. Three years of data from the Milford site and two years of data from the Blanding site are presented here.

Fifteen access tubes were installed in each of the three treatments (natural woodland, chained-with-debris-in-place, and chained-with debris-windrowed) at each site. Separate woodland controls for each treatment were maintained at Milford, since the two chaining treatments were some distance apart. Therefore, at Milford the total numbcr of access tubes was increased to 60 . Access tubes were installed to a depth of $120 \mathrm{~cm}$ with a rock drill at the Milford site and to $150 \mathrm{~cm}$ with soil auger at the Blanding site.

Access tubes were located throughout each 12- to 16-ha woodland and chain-with-debris-in-place treatment, the final exact location of each tube being determined by the required soil profile depth. On the debris-windrowed treatment, access tubes were generally installed between each set of windrows in the pattern shown in Figure 2. Given two windrows, access tube $X 1$ would be 5 to $7 \mathrm{~m}$ from the first (uppermost) windrow, $\mathrm{X} 2$ would be one-third to one-half the distance between the two windrows, and $X 3$ would be approximately $2 / 3$ the distance from the first windrow. On the next set of windrows, this pattern would be reversed, etc. Data were analyzed after preliminary examination, using standard analysis of variance techniques for a completely randomized design.

Jackrabbit populations on the Milford site were very high during the study. To prevent grazing, rabbit-proof fencing was installed to enclose a 4.5-m square area around each access tube on the chained areas. Fences were taken down each winter to prevent a snow fence effect around the access tubes.

The level of probability used for defining differences in this study was $10 \%$. It was felt that studies utilizing fewer replications per treatment at two distinct locations within the state was preferred to a more intensive study at a single site. As a result, the findings of this study can probably be extrapolated to other sites with a higher degree of reliability, but there is still the 1 in 10 chance that noted differences in soil moisture patterns among treatments are not real.

\section{Results}

\section{Milford}

Figures 4 and 5 show average centimeters of water per 30 $\mathrm{cm}$ of soil depth for a 2-year period for each chaining treatment and the respective woodland control. The trend was the same over a 3-year period. Averaged over all sampling dates, the debris-in-place treatment had more soil moisture throughout the $120-\mathrm{cm}$ profile than the woodland. The four soil depths $(30,60,90$, and $120 \mathrm{~cm})$ within the debris-in-place treatment and within the woodland all differed in moisture content.

In the debris-windrowed treatment, the amount of soil moisture in the surface $30 \mathrm{~cm}$ was very similar to the amount found in the woodland. At the $30-$ to $60-\mathrm{cm}$ soil depth, the woodland had more soil moisture than the debris-windrowed treatment. The debris-windrowed treatment had more soil moisture than the woodland in the last $60 \mathrm{~cm}$ of the $120-\mathrm{cm}$ soil profile. The four soil depths $(30,60,90$, and $120 \mathrm{~cm})$ within the debris-windrowed treatment and within the woodland all differed in moisture content, except for the $90-\mathrm{cm}$ and $120-\mathrm{cm}$ depths in the woodland. Most moisture flux took place in the upper $60-$ to $90-\mathrm{cm}$ of soil profile, with only minor changes occurring at greater depths.

In averaging data over all four sampling depths for each sampling date, it was obvious that the debris-in-place treatment consistently had more soil moisture during the first half of each year than the adjacent woodland (Table 1). This trend was not so pronounced in comparing the windrow treatment to the woodland. The debris-in-place treatment had more soil moisture than the woodland on 14 of 28 measuring dates. The debris-windrowed treatment had more soil moisture than the woodland on 9 of 28 measuring dates, the differences occurring primarily during the first half of each year.

The greatest difference between chained treatments and woodland occurred during the March-April period, when soil moisture storage reaches an annual peak. During all 3 years of the soil moisture study there was a slight increase in soil moisture caused by convectional thunderstorms from July

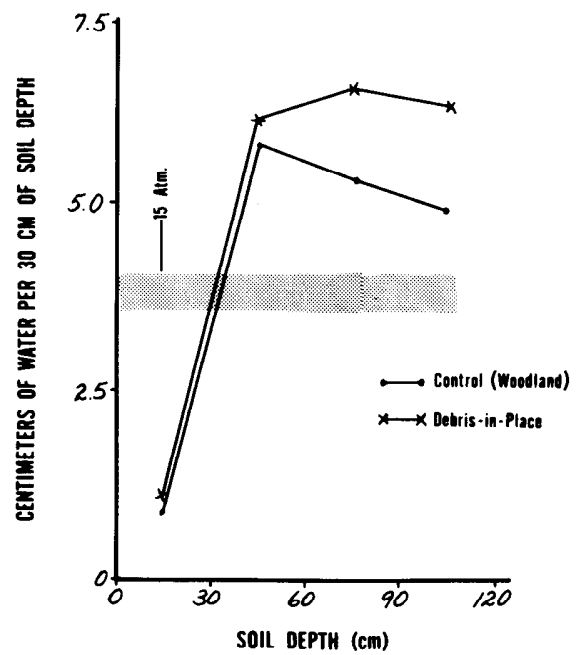

Fig. 4. Average centimeters of water per $30 \mathrm{~cm}$ of soil depth for debris-in-place treatment and adjacent woodland at Milford.

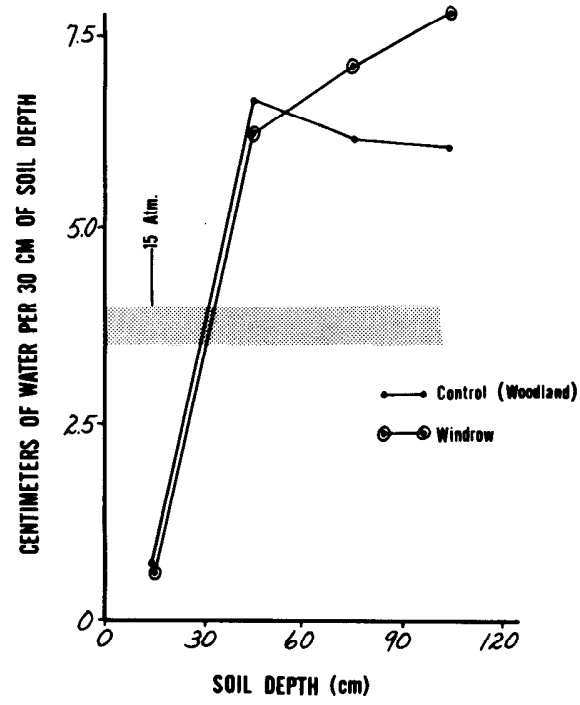

Fig. 5. Average centimeters of water per 30 $\mathrm{cm}$ of soil depth for debris-windrowed treatment and adjacent woodland at Milford.

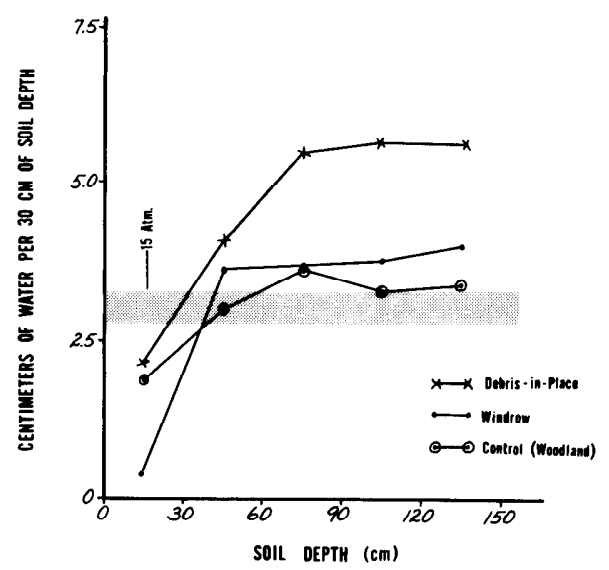

Fig. 6. Average centimeters of water per 30 $\mathrm{cm}$ of soil depth for all treatments at Blanding. 
Table 1. Average centimeters of water per $30 \mathrm{~cm}$ of soil profile on various dates at Milford study site. ${ }^{1}$

\begin{tabular}{|c|c|c|c|c|}
\hline \multirow[b]{2}{*}{ Date } & \multicolumn{2}{|c|}{ Chain-windrow } & \multicolumn{2}{|c|}{ Chain-debris-in-place } \\
\hline & $\begin{array}{c}\text { Woodland } \\
\text { control }\end{array}$ & treated & $\begin{array}{c}\text { Woodland } \\
\text { control }\end{array}$ & treated \\
\hline $9-24-69$ & 4.57 & 5.00 & 3.78 & 4.44 \\
\hline $12-15-69$ & 5.16 & 5.56 & 4.17 & $5.56^{\mathrm{a}}$ \\
\hline $3-07-70$ & 5.89 & 5.97 & 5.36 & $6.50^{\mathrm{a}}$ \\
\hline $3-28-70$ & 6.91 & 7.47 & 6.76 & 7.37 \\
\hline $4-21-70$ & 5.28 & $6.71^{\mathrm{a}}$ & 5.31 & $6.43^{\mathrm{a}}$ \\
\hline $5-22-70$ & 5.41 & 6.05 & 4.88 & $6.08^{\mathrm{a}}$ \\
\hline $6-23-70$ & 4.55 & $5.33^{\mathrm{a}}$ & 4.01 & $5.26^{\mathrm{a}}$ \\
\hline $7-24-70$ & 4.47 & $5.31^{\mathrm{a}}$ & 4.09 & 4.65 \\
\hline $8-04-70$ & 4.65 & 4.95 & 4.06 & 4.78 \\
\hline $8-18-70$ & 4.80 & 5.36 & 4.09 & 4.78 \\
\hline $9-04-70$ & 5.41 & 5.56 & 4.47 & 5.08 \\
\hline $10-03-70$ & 4.88 & 4.70 & 3.66 & 4.24 \\
\hline $3-10-71$ & 5.38 & $6.22^{\mathrm{a}}$ & 4.47 & $5.61^{\mathrm{a}}$ \\
\hline $6-08-71$ & 4.95 & $6.02^{\mathrm{a}}$ & 4.34 & $5.18^{\mathrm{a}}$ \\
\hline $6-18-71$ & 4.98 & $5.74^{\mathrm{a}}$ & 3.94 & $4.67^{\mathrm{a}}$ \\
\hline $7-21-71$ & 4.42 & 4.95 & 3.51 & $4.29^{\mathrm{a}}$ \\
\hline $8-05-71$ & 4.62 & 4.90 & 3.68 & 4.01 \\
\hline $8-17-71$ & 4.47 & 4.62 & 4.17 & 4.44 \\
\hline $9-05-71$ & 4.39 & 4.57 & 3.78 & 4.29 \\
\hline $11-11-71$ & 5.31 & $6.12^{\mathrm{a}}$ & 4.65 & $5.38^{\mathrm{a}}$ \\
\hline $2-19-72$ & 7.21 & 7.77 & 6.07 & $6.98^{a}$ \\
\hline 4-01-72 & 5.26 & $6.17^{\mathrm{a}}$ & 4.47 & $5.46^{\mathrm{a}}$ \\
\hline $5-28-72$ & 4.42 & $5.41^{a}$ & 3.84 & $4.57^{\mathrm{a}}$ \\
\hline $6-20-72$ & 4.32 & 4.93 & 3.76 & $4.47^{\mathrm{a}}$ \\
\hline $7-07-72$ & 4.42 & 4.80 & 3.48 & 3.84 \\
\hline $8-05-72$ & 4.09 & 4.44 & 3.38 & 3.63 \\
\hline $8-29-72$ & 5.23 & 5.33 & 3.71 & 4.24 \\
\hline $9-17-72$ & 4.17 & 4.42 & 3.35 & 3.71 \\
\hline
\end{tabular}

${ }_{1}^{1}$ All values with superscript $a$ are different $(P>0.10)$ from respective woodland controls.

through September.

\section{Blanding}

Results at the Blanding site are very similar to those found at Milford. Figure 6 shows the average centimeters of water per $30 \mathrm{~cm}$ of soil depth for 1 year for each chaining treatment and the woodland control. Analysis of 2 years of data gave the same relationships. The debris-in-place treatment had more soil moisture throughout the $150-\mathrm{cm}$ soil profile than either the debris-windrowed treatment or woodland. The woodland control had more soil moisture in the surface $30 \mathrm{~cm}$ of soil profile than the debris windrowed treatment. In the remaining $120 \mathrm{~cm}$ of soil profile, the debris-windrowed treatment had significantly more soil moisture than the woodland. Table 2 shows the average centimeters of water per $30 \mathrm{~cm}$ of soil profile on various dates for the different chaining treatments and woodland. The debris-in-place always had more soil moisture than the woodland, and the debris-windrowed treatment had more soil moisture than the woodland on 11 of 23 measuring dates.

\section{Discussion}

The different soil moisture patterns could have been a result of differing vegetation densities rather than a result of the chaining treatments. This factor was examined at each study site by using a point frame $150 \mathrm{~cm}$ in length, which had 25 equally spaced pins and was fastened directly to a given access tube. One hundred points were recorded around each access tube, 25 in each of the four cardinal directions, during September, 1971. Resultant data indicated the density of potential transpiring plant material. Regression analysis was used to determine the influence of vegetation density-on each chaining treatment-on soil moisture at three depths $(15,45$, and $75 \mathrm{~cm}$ ) on each of three dates during 1971. At Milford the debris-in-place treatment and the debris-windrowed treatment averaged 15.6 and $28.0 \%$, respectively, live vegetal ground cover around each access tube. The debris-in-place treatment and the debris-windrowed treatment at Blanding averaged $15.8 \%$ and $23.0 \%$, respectively, live vegetal ground cover around each access tube. Results of the analysis indicated that vegetation densities as measured in this study had no measureable effect on soil moisture patterns.

Differences in soil moisture patterns are due in part to differences in microclimates created by chaining as well as differences in rooting depths and length of growing season. On the debris-in-place treatments, wind speeds are probably reduced near the soil surface due to a boundary effect caused by scattered debris. Lack of this boundary effect on the debris-windrowed treatment causes increased wind turbulance and therefore greater vapor pressure gradients and increased evapotranspiration.

The mulching effect of litter on the debris-in-place plots could also be a significant factor. At Milford, litter averaged $32 \%$ on the debris-in-place treatment and only $7 \%$ on the debris-windrowed treatment. The debris-in-place treatment at Blanding averaged 54\% litter cover as compared with only $22 \%$ litter cover on the debris-windrowed treatment. Increased litter would mean decreased soil surface temperatures and decreased evaportation.

Differences in snow accumulation as a result of chaining may also account for some of the differences in soil moisture patterns between chained treatments. Limited data indicates the possibility of greater snow accumulation on debris-in-place plots, especially during periods with high snowfall.

As previously mentioned, most moisture flux took place in the upper 60 - to $90-\mathrm{cm}$ of soil profile with only minor changes

Table 2. Average centimeters of water per $30 \mathrm{~cm}$ of soil profile on various dates at Blanding study site. ${ }^{1}$

\begin{tabular}{rccc}
\hline \multicolumn{1}{c}{ Date } & Woodland & Chain-windrow & $\begin{array}{c}\text { Chain- } \\
\text { debris-in-place }\end{array}$ \\
\hline $7-26-70$ & 2.34 & 2.64 & 3.81 \\
$8-08-70$ & 2.64 & $3.10^{\mathrm{a}}$ & 4.47 \\
$8-22-70$ & 2.95 & $3.48^{\mathrm{a}}$ & 4.65 \\
$9-01-70$ & 2.77 & 3.12 & 4.42 \\
$9-14-70$ & 2.77 & $3.18^{\mathrm{a}}$ & 4.44 \\
$11-27-70$ & 2.77 & $3.58^{\mathrm{a}}$ & 4.57 \\
$4-03-71$ & 3.10 & $3.78^{\mathrm{a}}$ & 4.90 \\
$5-20-71$ & 2.72 & 3.02 & 4.34 \\
$6-08-71$ & 2.74 & 3.05 & 4.44 \\
$6-21-71$ & 2.57 & 2.79 & 3.71 \\
$7-08-71$ & 2.62 & $3.12^{\mathrm{a}}$ & 3.91 \\
$7-20-71$ & 2.62 & 2.84 & 4.19 \\
$8-02-71$ & 2.90 & 3.07 & 4.29 \\
$8-14-71$ & 3.35 & 3.05 & 4.06 \\
$11-04-71$ & 3.30 & $3.99^{\mathrm{a}}$ & 5.74 \\
$2-26-72$ & 4.29 & $4.93^{\mathrm{a}}$ & 5.69 \\
$4-13-72$ & 3.23 & $4.09^{\mathrm{a}}$ & 5.11 \\
$6-09-72$ & 2.79 & $3.23^{\mathrm{a}}$ & 4.47 \\
$6-24-72$ & 2.82 & $3.48^{\mathrm{a}}$ & 4.52 \\
$7-11-72$ & 2.72 & 3.07 & 4.22 \\
$7-20-72$ & 2.69 & 2.90 & 4.22 \\
$8-03-72$ & 2.69 & 3.05 & 3.99 \\
$9-12-72$ & 2.62 & 2.90 & 3.81 \\
\hline
\end{tabular}

${ }^{1}$ All values with superscript $a$ are different $(P>0.10)$ from respective woodland controls.

${ }^{2}$ Debris-in-place soil moisture values are all different $(P>0.10)$ from soil moisture values on windrow treatment. 
occurring at greater depths. Less soil moisture at the 90-, 120-, and $150-\mathrm{cm}$ depths in the woodland is due in part to deeper root penetration by the pinyon and juniper trees. Crested wheatgrass roots are concentrated in the surface $45 \mathrm{~cm}$ of soil profile, while juniper and pinyon roots are concentrated in the upper $90 \mathrm{~cm}$ of soil profile with sinker roots that penetrate even further. This, combined with a seasonal growth of crested wheatgrass as compared with pinyon and juniper, which may transpire a major part of the year, would contribute to less soil moisture in the woodland.

There is no evidence that surface soil moisture conditions have been improved enough on the debris-in-place treatments to affect seedling establishment. It is speculated that young trees missed in the chaining process and also deep-rooted shrub species on debris-in-place treatments may benefit most from increases in soil moisture, especially at soil depths beyond $60 \mathrm{~cm}$.

Finally, during the course of this study there was no indication of any excess moisture for eventual deep seepage.
Areas similar to the Milford site, which have had springs develop following chaining, are areas that have zones of subsurface flow as a result of snowmelt at elevations above the chaining project. The subsurface flow, which was normally consumed by the pinyon-juniper woodland, is not entirely consumed (transpired) under a grass cover. As a result, springs may develop or increase in flow as a result of the chaining. However, based on this study, the water is apparently not due to on-site additions to soil moisture.

\section{Literature Cited}

Brown, H. E. 1971. Evaluating watershed management alternatives. J. Irrig. \& Drainage Div., A.S.C.E. 97:93-108.

Collings, Mr. R. 1966. Effects of juniper and pinyon eradication on streamflow from Corduroy Creek Basin, Arizona. U. S. Geol. Surv. Prof. Pap. 491-B. 12 p.

Skau, C. M. 1964. Soil water storage under natural and cleared stands of alligator and Utah juniper in northern Arizona. Rocky Mountain Forest and Range Exp. Sta. U. S. Forest Serv. Res. Note RM-24. 3 p. 